\title{
Cellulose based Hybrid Separators for High Performance Li-ion Batteries
}

\author{
Meltem Yanılmaz ${ }^{1 *}$ \\ 1* Istanbul Technical University, Textile Engineering, İstanbul, Turkey, (ORCID: 0000-0003-0562-5715), yanilmaz@itu.edu.tr
}

(1st International Conference on Applied Engineering and Natural Sciences ICAENS 2021, November 1-3, 2021)

(DOI: 10.31590/ejosat.994727)

\begin{abstract}
ATIF/REFERENCE: Yanilmaz, M. (2021). Cellulose based Hybrid Separators for High Performance Li-ion Batteries. European
\end{abstract} Journal of Science and Technology, (28), 184-187.

\begin{abstract}
Separators not only affect the safety but also electrochemical performance and they are important components in lithium ion batteries. Many researches have been conducted to fabricate separators with high electrochemical properties and high thermal stability. High porosity is important for high performance and thermal stability is vital for safety of the cells. Electrospinning can be used to produce nanofibers with high thermal stability and high porosity. Ceramic particles could also be used to improve electrochemical performance. Electro-spraying can be applied to incorporate ceramic nanoparticles in separators. Cellulose based hybrid nanofiber membrane separators were prepared via electrospinning and electro-spraying. Morphology and structural properties of hybrid separators were studied by using SEM, XRD and FTIR. N-butanol was used for porosity measurements. EIS were used for ionic conductivity and interfacial resistance studies. Electrochemical performance of the hybrid separators was also evaluated for use as separator membrane in lithium-ion batteries. It was found that cellulose hybrid nanofiber membranes had superior electrochemical performance with good electrochemical stability due to large porosity of nanofibers and electro-sprayed $\mathrm{SiO}_{2}$ nanoparticles. Large liquid electrolyte uptake of $240 \%$, high electrochemical oxidation limit of over $4.5 \mathrm{~V}$, and low interfacial resistance of $190 \mathrm{ohm} \cdot \mathrm{cm}^{2}$ with lithium were observed when hybrid membranes were used in $\mathrm{Li} / \mathrm{LiFePO}_{4}$ cells. In addition, high cell capacities of above $160 \mathrm{mAh} / \mathrm{g}$ and good cycling performance were demonstrated.
\end{abstract}

Keywords: Electrospinning, Electrospraying, battery, Separator, Li-ion battery

\section{Yüksek Performanslı Lityum iyon Bataryaları için Selüloz Hibrit Ayıricılar}

$\ddot{\mathbf{O z}}$

Lityum iyon bataryalarda ayırıcılar sadece güvenliği değil elektrokimyasal performansı da etkiler ve bataryalarda önemli bir bileşendir. Yüksek elektrokimyasal özelliklere ve yüksek ısıl dayanıma sahip ayırıcı geliştirmek için birçok araştırma yapılmaktadır. Yüksek gözeneklilik performans için ve ısıl dayanım batarya güvenliği açısından önem taşımaktadır. Elektroeğirme tekniği ile yüksek ısıl dayanım ve yüksek gözenekliliğe sahip nanolifler üretilebilir. Ayrıca seramik parçacıkları elektrokimyasal performansı artırmak için kullanılabilir. Elektro-spray işlemi ile seramik nanoparçacıklar içeren ayırıcılar üretilebilir. Çalışmada elektroeğirme ve elektro-spray teknikleri kullanılarak selüloz hibrit ayırıcılar üretilmiştir. Hibrit ayırıcıların morfoloji ve yapısal özellikleri SEM, XRD ve FTIR kullanılarak incelenmiştir. Gözeneklilik ölçümleri için N butanol kullanıldı. İyonik iletkenlik ve arayüzey dirençleri için ise EIS kullanıldı. Hibrit ayırıcıların lityum iyon bataryalarında elektrokimyasal performansları incelendi. Yüksek gözeneklilik ve $\mathrm{SiO}_{2}$ parçacıkları elektrokimyasal performansın yüksek ve elektrokimyasal dayanımın iyi olmasına katkı sağladı. $\mathrm{Li} / \mathrm{LiFePO}_{4}$ bataryalarında hibrit ayırıcı kullanıldığında yüksek elektrolit adsorpsiyonu, $240 \%$, yüksek elektrokimyasal dayanım, $>4.5 \mathrm{~V}$, lityum ile düşük arayüz direnci $190 \mathrm{ohm} \cdot \mathrm{cm}^{2}$ gözlendi. Ayrıca, $160 \mathrm{mAh} / \mathrm{g}$ in üzerince kapasite ve iyi şarj-deşarj performansı görüldü.

Anahtar Kelimeler: Electroeğirme, Electro spray, Batarya, Ayırıcı, Li-iyon batarya

\footnotetext{
* Corresponding Author: yanilmaz@,itu.edu.tr
} 


\section{Introduction}

Li-ion batteries have been gained great attention due to superior properties including high specific energy, long cycle life, low self-discharge rate, no memory, and long shelf life. Even though, many research have been conducted on materials for Liion batteries, the safety and performance of the cells should be improved for new applications such as electric cars and large scale energy storage systems (Lee, Yanilmaz, Toprakci, Fu, \& Zhang, 2014), (Zhao et al., 2021).

Separators are placed between two electrodes to prevent physical contact of electrodes and they allow ion movements owing to their porous structure. Mechanical and thermal stability is important to prevent short circuit. In addition, highly porous structure is required to reduce cell resistance and thus improve electrochemical properties (Yanilmaz, Zhu, Lu, Ge, \& Zhang, 2017).

Electrospinning is a common technique to produce nanofibers and polymers such as polyvinylidene fluoride, polyacrylonitrile, poly(methyl methacrylate), etc. have been used to produce nanofibers. However, considering environmental issues, it is important to use natural polymers to produce nanofibers for high performance separators. Moreover, it has been shown that ceramic nanoparticles could improve electrochemical performance of the separators (Yanilmaz, 2020),(Zaidi et al., 2020).

In this study, cellulose hybrid separators were fabricated using electrospinning and electro-spraying methods. Electrospinning of cellulose acetate provided high porosity and electrospraying of $\mathrm{SiO}_{2}$ ceramic nanoparticles led to improved electrochemical performance.

\section{Material and Method}

Cellulose acetate was dissolving in $\mathrm{N}, \mathrm{N}$-dimethylformamide (DMF) and $\mathrm{SiO}_{2}$ nanoparticles were dispersed in acetone. During electrospinning, the feeding rate of $1 \mathrm{ml} / \mathrm{h}$, applied voltage of 15 $\mathrm{kV}$ were used and the distance between the collector and the needle was $15 \mathrm{~cm}$. In electro-spraying, the same distance, feeding rate and the voltage was set in order to produce hybrid separators. All chemicals were used as received without further purification. The morphologies was studied by using scanning electron microscopy. The porosities and electrolyte uptake capacities of the membranes were determined by using uptake tests. X-ray diffraction and FTIR analysis were conducted for structural characterization. Electrochemical impedance spectroscopy (EIS) and cyclic tests were used for electrochemical characterization. $\mathrm{Li} / \mathrm{LiFePO}_{4}$ cells were prepared for cycling tests.

Table 1. Porosity, electrolyte uptake, ionic conductivity, interfacial resistance

\begin{tabular}{l|c|c|c|c}
\hline & Porosity, \% & $\begin{array}{c}\text { Electrolyte } \\
\text { uptake, \% }\end{array}$ & $\begin{array}{c}\text { Ionic conductivity, } \\
\mathbf{m S} \cdot \mathbf{c m}^{-\mathbf{1}}\end{array}$ & $\begin{array}{c}\text { Interfacial } \\
\text { resistance, } \\
\mathbf{o h m} \cdot \mathbf{c m}^{\mathbf{2}}\end{array}$ \\
\hline Cellulose based separator & 70 & 240 & 2 & 300 \\
\hline Hybrid separator & 77 & 290 & 2.4 & 190 \\
\hline PP separator & 41 & 158 & 0.8 & 410 \\
\hline
\end{tabular}

\section{Results and Discussion}

Hybrid separators were prepared via electrospinning of cellulose and electro-spraying of $\mathrm{SiO}_{2}$ nanoparticles. SEM images of cellulose based separator and hybrid separator were shown in Fig. 1 and Fig. 2, respectively. Fibrous structure without defects were observed in Fig. 1 and uniform ceramic nanoparticle coating was seen in Fig. 2. Separators are porous membranes and their physical properties affect the safety and cell performance. Highly porous separators allow fast movement of ions and thus improve electrochemical performance. As seen in Fig 1, cellulose membrane has nanofibrous structure without any defects. Fig. 2 shows ceramic nanofiber coating on fibrous membranes. Owing to the electro-spraying approach, uniform coating of $\mathrm{SiO}_{2}$ are achieved on highly fibrous structure. Previous studies reported the inclusion of nanoparticles in nanofibers by adding nanoparticles into polymer solution and electrospun this composite solution into nanofibers. However, in this technique the amount of particles

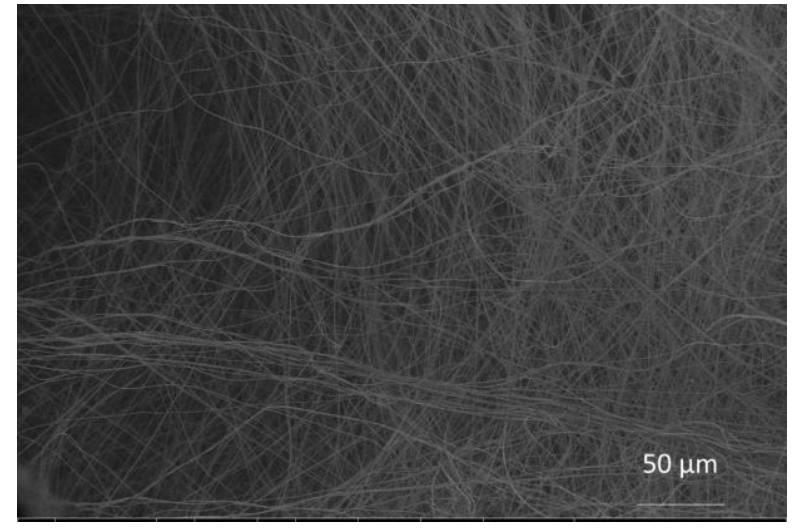

Fig. 1 SEM image of cellulose based separators

limited to around $10 \%$ of the polymers used and nanoparticles led to irregular morphology which is detrimental to the cell performance. However, large amount of ceramic nanoparticles could be added in the membrane without changing the morphology of nanofibers which is promising for high performance cells. In addition, using thermally stable cellulose based nanofibers are also beneficial for safety of the cells. 


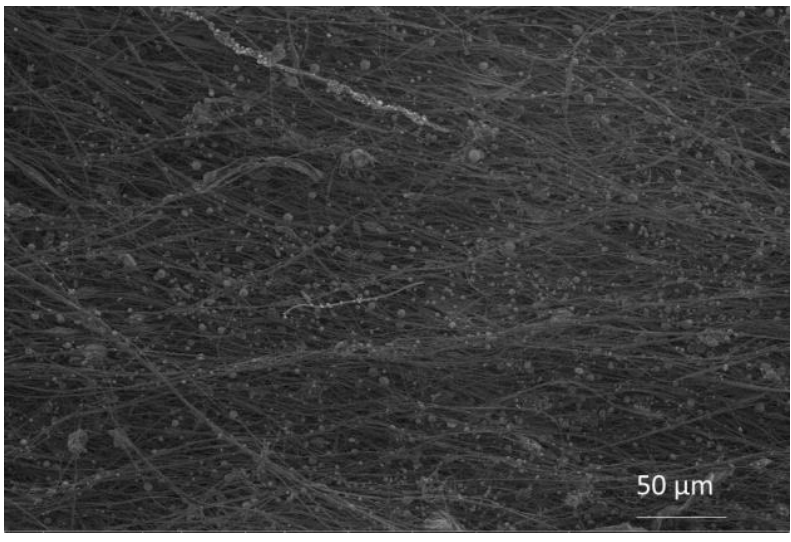

Fig. 2 SEM image of hybrid separators

EDX spectrum of hybrid separators and cellulose separators were given in Fig.3. The peak related to Si was seen in the spectrum.

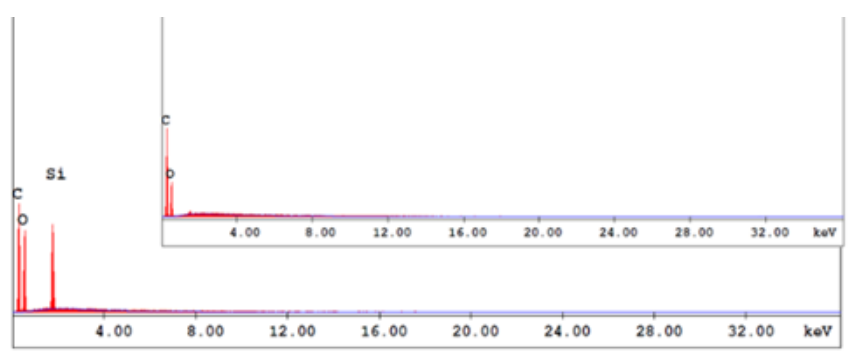

Fig.3 EDX spectrum of hybrid separators (inset: EDX spectrum of cellulose based separators)

FTIR and XRD spectra of cellulose based and hybrid separators are seen in Fig. 4 and Fig.5, respectively.

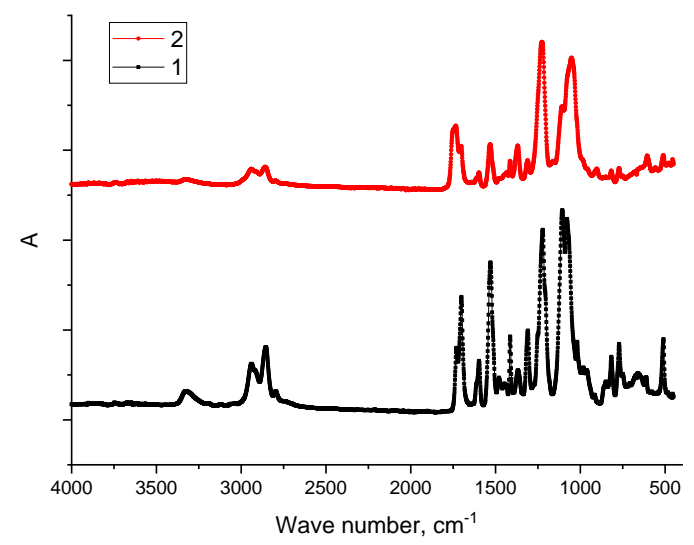

Fig. 4 FTIR spectra of cellulose based separators (1) and hybrid separators (2)

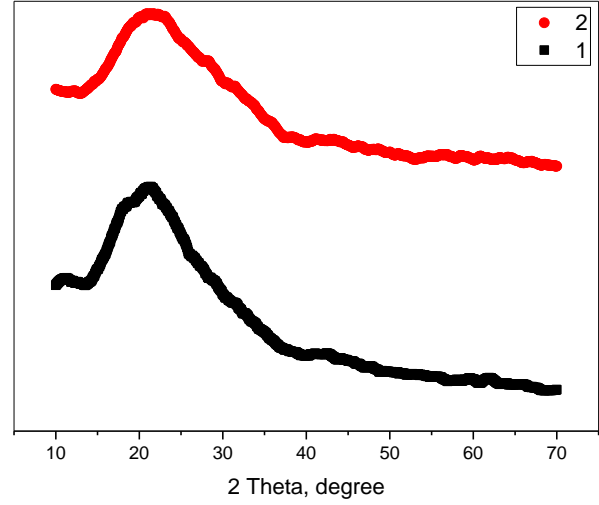

Fig. 5 XRD spectra of cellulose based separators (1) and hybrid separators (2)

EDX spectra of hybrid membrane show the presence of $\mathrm{SiO}_{2}$ in the separators. The characteristic peaks of cellulose acetate are the peaks attributed to $\mathrm{OH}$ stretching, $\mathrm{CH}$ stretching, $\mathrm{C}=\mathrm{O}$ stretching of acetyl group, $\mathrm{CO}$ stretching of acetyl group, COC stretching of acetyl group (Fei, Liao, Cheng, \& Song, 2017) and these peaks were seen around $3460 \mathrm{~cm}^{-1}, 2940 \mathrm{~cm}^{-1}, 1750 \mathrm{~cm}^{-1}$, $1240 \mathrm{~cm}^{-1}, 1050 \mathrm{~cm}^{-1}$, respectively in FTIR spectra of separators.

X-ray diffraction analysis could be used to study change in crystalline nature, crystallographic structure, chemical composition, and physical properties. In XRD spectra of cellulose and hybrid separators, a wide peak around $20^{\circ}$ are seen which is typical for semi crystalline polymers (de Freitas, Senna, \& Botaro, 2017). The peak becomes broader in hybrid separators due to the amorphous nature of $\mathrm{SiO}_{2}$ nanoparticles.

Porosity is one of the main feature of separators that affect the cell resistance. High porosity with good mechanical properties are essential to reach high specific energy. In commercial batteries, PP membranes are used and this microporous membranes have limited porosity and have poor affinity to the electrolyte which limits the performance of the cells (Yanilmaz et al., 2017).

As shown in Table 1, the porosity of cellulose based separator is $70 \%$ and inclusion of ceramic particles increases the porosity up to $77 \%$. The increase could be attributed to the high specific surface area and amorphous structure of the $\mathrm{SiO}_{2}$ nanoparticles. However, PP membrane has a low porosity of $41 \%$.

Electrolyte uptake is another important property that influence the performance of the cells. The electrolyte uptake values of cellulose based and PP membranes are $240 \%$ and $158 \%$, respectively. Electrospun separators have higher electrolyte uptake values owing to the higher porosity compared to microporous PP membrane. The hybrid separator has the highest uptake capacity of $290 \%$ compared to those of cellulose and PP membranes. The high electrolyte uptake of hybrid membranes could be attributed to high porosity of nanofibrous membrane and affinity of ceramic nanoparticles to the electrolyte. High electrolyte uptakes was also reported for $\mathrm{SiO}_{2}$ containing polyvinyl alcohol membranes (Yanilmaz, 2020). Ahn et al (Ahn et al., 2020) also reported superior wettability with the addition of ceramic particles on PE membrane.

Ionic conductivities of the hybrid, cellulose and PP membranes were also calculated. Owing to the high porosity and $\mathrm{SiO}_{2}$ addition, the hybrid membrane has the highest ionic conductivity of $2.4 \mathrm{mS} / \mathrm{cm}^{2}$ whereas the ionic conductivity of cellulose membrane is $2 \mathrm{mS} / \mathrm{cm}^{2}$. PP membrane has the ionic conductivity 
of only $0.8 \mathrm{mS} / \mathrm{cm}^{2}$ because of its low porosity and poor affinity of PP membrane to the electrolyte.

The cell performance was directly related to the cell resistance and low resistance is required for long cycling life with high capacity. Cell resistance are also important for high C-rates. Interfacial resistance of the $\mathrm{Li} / \mathrm{LiFePO}_{4}$ cells prepared with hybrid and cellulose separators are evaluated and hybrid membrane delivers the low interfacial resistance of $190 \mathrm{ohm} \cdot \mathrm{cm}^{2}$ compared to that $\left(300 \mathrm{ohm} \cdot \mathrm{cm}^{2}\right)$ of cellulose membrane. The low resistance of hybrid membrane was related to the $\mathrm{SiO}_{2}$ coating. Low interfacial resistance with ceramic layer addition was also reported for polyolefin membranes (Ahn et al., 2020).

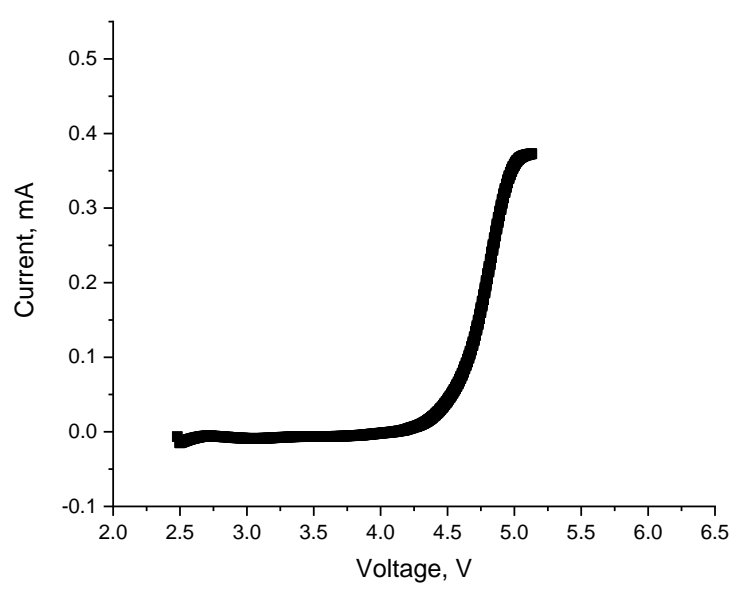

Fig. 6 LSV of hybrid separators.

Fig. 6 shows the linear sweep voltammetry curve of the cell prepared with hybrid separators. The $\mathrm{C}$ rate performance of the $\mathrm{Li} / \mathrm{LiFePO}_{4}$ cells prepared with $\mathrm{PP}$ membrane, cellulose membrane and hybrid membrane was reported in Fig.7. High specific capacity was observed when hybrid separators were used.

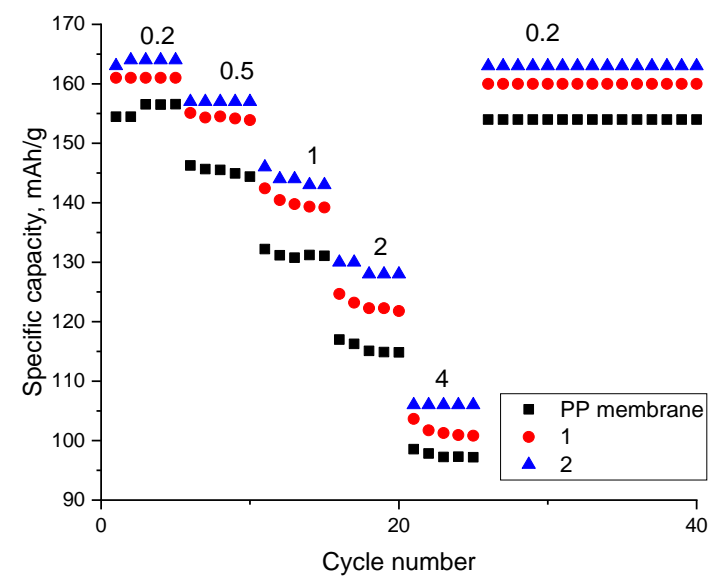

Fig. 7 C-rate performance of cellulose based separators (1) and hybrid separators (2).

Linear sweep voltammetry (LSV) curves are seen in Fig. 6 and as seen from the figure the cell prepared with hybrid membrane can be cycled over $4.5 \mathrm{~V}$ without electrolyte decomposition which is an important property for high energy density.

Fig. 7 reports C-rate performance of the $\mathrm{Li} / \mathrm{LiFePO}_{4}$ cells prepared with hybrid, cellulose and PP membranes. The cell with the hybrid membrane delivers the specific capacity of over 160
$\mathrm{mAh} / \mathrm{g}$ whereas the cell with PP membrane has the capacity of around $150 \mathrm{mAh} / \mathrm{g}$ at $0.2 \mathrm{C}$. As C-rate increases, the cell with hybrid membrane delivers higher capacity compared to those with cellulose and PP membrane. The capacity is over $105 \mathrm{mAh} / \mathrm{g}$ whereas the cell with PP membrane delivers the capacity around $95 \mathrm{mAh} / \mathrm{g}$ at $4 \mathrm{C}$. When the C-rate goes back to $0.2 \mathrm{C}$, the cell with hybrid membrane still delivers high capacities. The high $\mathrm{C}$-rate performance of hybrid membrane could be attributed to high porosity with high ionic conductivity and low interfacial resistance.

\section{Conclusions and Recommendations}

Cellulose hybrid separators with high electrochemical stability and large porosity were fabricated by using electrospinning and electro-spraying. The highly porous nanofibrous structure was studied via SEM. The presence of $\mathrm{SiO}_{2}$ was shown with structural characterization studies. Ionic conductivity, electrolyte uptake, interfacial resistance of the studied separators were investigated. Owing to the presence of $\mathrm{SiO}_{2}$ nanoparticles and porous nanofibers, hybrid membrane had the highest porosity and electrolyte uptake capacities. In addition, the cell prepared with hybrid separators delivered higher capacities comparted to cell with commercial PP membrane. Results showed that electrospraying is a facile approach to fabricate hybrid separators for high performance batteries.

\section{References}

Ahn, J. H., You, T.-S., Lee, S.-M., Esken, D., Dehe, D., Huang, Y.-C., \& Kim, D.-W. (2020). Hybrid separator containing reactive, nanostructured alumina promoting in-situ gel electrolyte formation for lithium-ion batteries with good cycling stability and enhanced safety. Journal of Power Sources, 472, 228519.

De Freitas, R. R., Senna, A. M., \& Botaro, V. R. (2017). Influence of degree of substitution on thermal dynamic mechanical and physicochemical properties of cellulose acetate. Industrial crops and products, 109, 452-458.

Fei, P., Liao, L., Cheng, B., \& Song, J. (2017). Quantitative analysis of cellulose acetate with a high degree of substitution by FTIR and its application. Analytical Methods, 9(43), 61946201.

Lee, H., Yanilmaz, M., Toprakci, O., Fu, K., \& Zhang, X. (2014). A review of recent developments in membrane separators for rechargeable lithium-ion batteries. Energy \& Environmental Science, 7(12), 3857-3886.

Yanilmaz, M. (2020). Evaluation of electrospun PVA/SiO2 nanofiber separator membranes for lithium-ion batteries. The Journal of The Textile Institute, 111(3), 447-452.

Yanilmaz, M., Zhu, J., Lu, Y., Ge, Y., \& Zhang, X. (2017). Highstrength, thermally stable nylon 6,6 composite nanofiber separators for lithium-ion batteries. Journal of Materials Science, 52(9), 5232-5241.

Zaidi, S. D. A., Wang, C., Shao, Q., Gao, J., Zhu, S., Yuan, H., \& Chen, J. (2020). Polymer-free electrospun separator film comprising silica nanofibers and alumina nanoparticles for Li-ion full cell. Journal of Energy Chemistry, 42, 217-226.

Zhao, X., Wang, W., Huang, C., Luo, L., Deng, Z., Guo, W., . . . Meng, Z. (2021). A novel cellulose membrane from cattail fibers as separator for Li-ion batteries. Cellulose, 1-13. 